\title{
Genetic Analysis of Isolates of Botrytis cinerea Sensitive and Resistant to Benzimidazole and Dicarboximide Fungicides
}

\author{
L. F. Yourman, S. N. Jeffers, and R. A. Dean
}

- Department of Plant Pathology and Physiology, Clemson University, Clemson, SC 29634-0377.

Current address of L. F. Yourman: USDA, ARS Foreign Disease-Weed Science Research Unit, 1301 Ditto Avenue, Ft. Detrick, MD 21702-5023.

Current address of R. A. Dean: Fungal Genomics Laboratory, 840 Main Campus Drive, Campus Box 7251, North Carolina State University, Raleigh 27695-7251.

Accepted for publication 25 April 2000.

\begin{abstract}
Yourman, L. F., Jeffers, S. N., and Dean, R. A. 2000. Genetic analysis of isolates of Botrytis cinerea sensitive and resistant to benzimidazole and dicarboximide fungicides. Phytopathology 90:851-859.

A total of 56 isolates of $B$. cinerea collected from ornamental crops from commercial greenhouses were examined by random amplified polymorphic DNA (RAPD) fingerprint analyses. Isolates were examined as two independent sets of 35 and 36 isolates, with 15 isolates common to both sets. The isolates had four phenotypes: 17 were sensitive to two commonly used fungicides, thiophanate-methyl (a benzimidazole) and vinclozolin (a dicarboximide) $\left(\mathrm{S}^{\mathrm{T}} \mathrm{S}^{\mathrm{V}}\right)$; 18 were resistant to both fungicides $\left(\mathrm{R}^{\mathrm{T}} \mathrm{R}^{\mathrm{V}}\right)$; 16 were resistant to thiophanate-methyl but sensitive to vinclozolin $\left(\mathrm{R}^{\mathrm{T}} \mathrm{S}^{\mathrm{V}}\right)$; and 5 were sensitive to thiophanate-methyl but resistant to vinclozolin $\left(S^{T} R^{V}\right)$. Relationships among the isolates were determined by cluster analyses of mean character differences using the unweighted pair group method using arithmetic average and cladograms were constructed. Isolates were clustered primarily by fungicide-sensitivity phenotype. In one set of greenhouse isolates, 6 of $10 \mathrm{~S}^{\mathrm{T}} \mathrm{S}^{\mathrm{V}}$ isolates clustered together with a bootstrap confidence value of $91 \%$. In the other

fingerprint set of greenhouse isolates, 9 of $11 \mathrm{~S}^{\mathrm{T}} \mathrm{S}^{\mathrm{V}}$ isolates clustered together and had a bootstrap confidence value of $98 \%$. Isolates resistant to thiophanate-methyl, vinclozolin, or both fungicides usually were not clustered with other isolates or were clustered with isolates of the same phenotype. To further elucidate these relationships, variant isolates resistant to one or both fungicides were produced on fungicide-amended agar medium from $14 \mathrm{~S}^{\mathrm{T}} \mathrm{S}^{\mathrm{V}}$ greenhouse isolates. These $14 \mathrm{~S}^{\mathrm{T}} \mathrm{S}^{\mathrm{V}}$ parent isolates, 57 resistant variant isolates, and 11 resistant greenhouse isolates were analyzed as three independent RAPD fingerprint sets. Variants selected from eight $\mathrm{S}^{\mathrm{T}} \mathrm{S} \mathrm{V}$ parent isolates were resistant to both thiophanate-methyl and vinclozolin even though parent isolates were exposed to only one of the fungicides. Isolates resistant only to vinclozolin $\left(\mathrm{S}^{\mathrm{T}} \mathrm{R}^{\mathrm{V}}\right)$ had fingerprint patterns similar to and clustered with those of parent isolates, while fingerprint patterns of isolates resistant to thiophanate-methyl (i.e., $R^{T} R^{V}$ or $R^{T} S^{V}$ ), regardless of sensitivity to vinclozolin, clustered differently from both those of $S^{\mathrm{T}} \mathrm{S}^{\mathrm{V}}$ parent isolates and those of $S^{T} R^{V}$ isolates derived from the same parent. $R^{T} R^{V}$ and $R^{T} S^{V}$ variant isolates derived from the same fungicide-sensitive parents only clustered with other variants having the same phenotype.
\end{abstract}

Botrytis cinerea Pers.:Fr. is a common and economically important pathogen of numerous greenhouse-grown ornamental crops $(4,16)$. Ornamental crops grown in greenhouses and nurseries are some of the most valuable agricultural products in the United States; greenhouse-grown ornamental crops alone had an estimated value of $\$ 3.5$ billion in 1993 (8). To reduce the negative impact of Botrytis blight, an effective management strategy should include sanitation and other cultural practices as well as fungicide applications to prevent or limit disease spread $(4,16)$. Because host resistance to $B$. cinerea is not available for most plants, fungicides are important for managing leaf, stem, and flower blights in greenhouse crop production. However, resistance to the most commonly used classes of fungicides, the benzimidazoles and dicarboximides, has compromised the effectiveness of these fungicides in many populations of $B$. cinerea (2). Resistance complicates disease management and can lead to serious economic losses. Although benzimidazoles (e.g., thiophanatemethyl) have been used most commonly to control many foliar pathogens in greenhouses (8), dicarboximides (e.g., vinclozolin) may be more effective for managing $B$. cinerea (16).

Benzimidazole-resistant isolates of $B$. cinerea persist long after the use of benzimidazole fungicides is discontinued $(9,21,24,37)$.

Corresponding author: S. N. Jeffers; E-mail address: sjffrs@ clemson.edu

Publication no. P-2000-0531-01R

(c) 2000 The American Phytopathological Society
Dicarboximide fungicides were introduced in the mid-1970s, and within a decade, dicarboximide-resistant isolates were common on several crops $(15,19,23,24,30,31)$. The incidence of fungicide resistance in populations of $B$. cinerea has become so common on ornamental crops that in some regions these fungicides no longer are recommended for use (29). Reversion of resistant populations to ones with fungicide sensitivity has not been observed even after selection pressure has been removed; resistant populations have persisted even with minimal or no fungicide use $(21,31)$.

Recently, 325 isolates of $B$. cinerea were collected from ornamental crops in 35 commercial greenhouses in 16 counties of South Carolina (42). Isolates resistant to thiophanate-methyl or vinclozolin were found in 32 of 35 greenhouses. Resistance to both fungicides was the most common phenotype found, accounting for $67 \%$ of all isolates collected, and only $17 \%$ of the isolates were sensitive to both fungicides. Of the remaining isolates, $14 \%$ were resistant to thiophanate-methyl and sensitive to vinclozolin, and only $2 \%$ (six isolates) were sensitive to thiophanate-methyl and resistant to vinclozolin.

Random amplified polymorphic DNA (RAPD) fingerprint analysis has been a useful technique to study geographic variation within species and to detect clonal diversity (12). It has been used to identify genetic variation in several plant-pathogenic fungi, e.g., Fusarium oxysporum (1), Magnaporthe poae (14), Alternaria spp. (34), and Ophiostoma piceae (32). Despite its importance as a plant pathogen, reports of genetic diversity in populations of $B$. cinerea have been limited. In the Netherlands, RAPD-marker 
polymorphisms were found among 29 isolates of $B$. cinerea having different virulence characteristics; however, there was no correlation between genetic polymorphism and virulence, time of sampling, or sampling location (20). Resistance of the isolates to fungicides was not an objective of that study.

A genetic approach to the study of variation among isolates of $B$. cinerea that differ in fungicide sensitivity is reported here. The first objective was to use RAPD technology and cluster analysis to determine the genetic diversity and relatedness among greenhouse isolates of $B$. cinerea that differed in sensitivity to the fungicides thiophanate-methyl and vinclozolin. The second objective was to use fungicide-resistant variant isolates derived from fungicide-sensitive greenhouse isolates to further elucidate genetic relationships among isolates that differed in fungicide sensitivity. A preliminary report has been published (43).

\section{MATERIALS AND METHODS}

Fungicides. Commercial flowable formulations of thiophanatemethyl (Cleary's 3336F, 46\% active ingredient [a.i.] by weight) and vinclozolin (Curalan, $41.3 \%$ a.i. by weight) were used. Fungicides were stored at $15^{\circ} \mathrm{C}$ in the dark to maintain and preserve fungicide activity.

Isolates of $\boldsymbol{B}$. cinerea. A total of 56 isolates of $B$. cinerea was selected for genetic examination; 55 isolates were selected from among 325 greenhouse isolates recently collected in South Carolina (42). These 55 isolates came from diseased ornamental plants-primarily geranium, poinsettia, impatiens, and begoniafrom 30 different greenhouses (Table 1). One additional isolate, DC-5, was recovered from a diseased geranium growing in the landscape in Washington, DC. Previously, phenotype designations were determined by conidium germination and mycelium growth on fungicide-amended minimal nutrient medium, and virulence was determined by a geranium seedling bioassay (42). Four phenotypes were identified: seventeen isolates (including isolate DC-5) were sensitive to both thiophanate-methyl and vinclozolin $\left(\mathrm{S}^{\mathrm{T}} \mathrm{S}^{\mathrm{V}}\right)$, eighteen isolates were resistant to both fungicides $\left(\mathrm{R}^{\mathrm{T}} \mathrm{R}^{\mathrm{V}}\right)$, sixteen isolates were resistant to thiophanate-methyl and sensitive to vinclozolin $\left(\mathrm{R}^{\mathrm{T}} \mathrm{S}^{\mathrm{V}}\right)$, and five isolates were sensitive to thiophanate-methyl and resistant to vinclozolin $\left(S^{\mathrm{T}} \mathrm{R}^{\mathrm{V}}\right)$.

For this study, phenotypes were verified by testing conidia from all isolates for germination on a defined minimal medium, as described previously (42), amended with either thiophanate-methyl or vinclozolin at $5 \mu \mathrm{g} / \mathrm{ml}$. Conidium suspensions were standardized to a concentration of 2 to $3 \times 10^{4}$ conidia per $\mathrm{ml}$ with a hemacytometer; $10-\mu$ drops were pipetted onto the surface of the medium; and approximately 20 drops were added to a dish. Conidium suspensions also were pipetted onto unamended medium as controls. Dishes containing conidia were placed in the dark at $20^{\circ} \mathrm{C}$ for 14 to $18 \mathrm{~h}$ to allow conidia to germinate. Agar surfaces were covered with a solution of $0.025 \%$ aniline blue in $50 \%$ lactic acid to stop fungus growth and facilitate enumeration of conidia with a microscope $(50 \times)$. Germination rate was determined by counting the number of conidia out of 100 that had germ tubes with lengths at least three times the diameter of a conidium and that grew into the agar and appeared normal. Conidia of individual isolates were consistent in their responses to fungicideamended media, i.e., at least $93 \%$ of conidia of any isolate responded similarly to fungicide exposure. Isolates with conidia that germinated on fungicide-amended medium were designated resistant to that fungicide.

All isolates were stored in an ultra-low-temperature freezer $\left(-80^{\circ} \mathrm{C}\right)$ in $15 \%$ glycerol in $2-\mathrm{ml}$ cryogenic vials (Nalgene Corporation, Rochester, NY) and were retrieved from storage as described previously (42). Retrieved conidia were used as propagules to start mycelium cultures for DNA extraction (described below) and to verify phenotype designation with the conidium germination assay (described above).
Selection of fungicide-resistant variants. To further study genetic variation and relationships identified among the 56 greenhouse isolates of $B$. cinerea, isolates resistant to one or both of the fungicides with known pedigrees were needed. Therefore, resistant variants (i.e., asexual clonal derivatives) were selected from parent isolates sensitive to both fungicides. In 1997, conidia of $15 \mathrm{~S}^{\mathrm{T}} \mathrm{S}^{\mathrm{V}}$ isolates of $B$. cinerea (each from a distinct collection site) were harvested from dishes of potato dextrose agar (PDA) and placed in suspension in $0.01 \%$ Tween 80. Conidium suspensions ( 1 to $5 \times 10^{6}$ conidia per $\mathrm{ml}$ ) were spread on petri dishes containing the minimal medium described above amended with a single fungicide - either thiophanate-methyl at $10 \mu \mathrm{g} / \mathrm{ml}$ or vinclozolin at $5 \mu \mathrm{g} / \mathrm{ml}$. Conidia from each of the 15 isolates were spread on medium amended with thiophanate-methyl and on medium amended with vinclozolin, with five dishes per isolate for each fungicide; dishes were placed at $20^{\circ} \mathrm{C}$ in the dark for 5 days. All 15 isolates produced some normal colonies after 5 days on fungicide-amended medium; colonies were subcultured by placing hyphal tips on the same fungicide-amended medium from which they had been selected. These variants were placed at $20^{\circ} \mathrm{C}$ in the dark for 3 days, and 12 of the 15 isolates continued to produce apparently normal colonies. Tips of hyphae from these colonies were transferred to unamended PDA for further growth and conidium production. Parent isolates yielded at least one normalappearing variant isolate that was resistant to at least one fungicide. A total of 70 variant isolates were selected and assayed by conidium germination for phenotype designation; conidia then were stored in a freezer at $-80^{\circ} \mathrm{C}$.

A similar selection procedure was conducted in 1998, with 26 $\mathrm{S}^{\mathrm{T}} \mathrm{S}^{\mathrm{V}}$ isolates used as parents. After 5 days on fungicide-amended medium, 20 of the 26 isolates yielded at least one normalappearing colony. After hyphal tips were transferred to fungicideamended media and incubated for 3 days, 12 of the 20 sensitive parent isolates yielded viable and normal-appearing colonies. A total of 78 variant isolates were selected from these 12 parents, and hyphae of these isolates were transferred to PDA for conidium production. Conidia were tested with the germination assay to verify phenotypes, and conidium suspensions were stored at $-80^{\circ} \mathrm{C}$. Six parent isolates were common to both selection procedures that were conducted in 1997 and 1998. The rate of occurrence of variant isolates in the two selection procedures ranged from approximately $10^{-4}$ to $10^{-8}$. Of the 148 resistant variants selected in both years, 57 isolates were used in this study. $\mathrm{EC}_{50}$ values were calculated (42) for variant isolates based on a mycelium growth assay on nutrient agar medium amended with thiophanatemethyl at $0,0.05,0.1,0.5,1,2,5,50$, or $500 \mu \mathrm{g} / \mathrm{ml}$ and vinclozolin at $0,0.05,0.1,0.2,0.5,1,2,3,10$, or $100 \mu \mathrm{g} / \mathrm{ml}$. Isolates were considered resistant when $\mathrm{EC}_{50}$ values were equal to or greater than $1 \mu \mathrm{g}$ per $\mathrm{ml}$ of thiophanate-methyl or vinclozolin (Table 2).

Isolate nomenclature. Greenhouse isolates were given identification numbers that consisted of uppercase letters to indicate the geographic site of collection (Table 1), a number indicating the individual isolate from that site, and a lowercase letter, $a$ or $b$, if two isolates were collected from the same piece of diseased plant tissue. Variant isolates were designated by the number of the parent isolate followed by $/ \mathrm{T}$ or $/ \mathrm{V}$ to indicate selection on thiophanate-methyl- or vinclozolin-amended medium, respectively, and a number or letter to identify individual variants (Table 2).

Preparation of mycelia. Gamborg's B-5 basal medium (broth) with vitamins and minimal organic compounds (Sigma BioSciences, St. Louis, MO) was prepared according to the label (3.2 g/liter). Sterile $30 \%$ glucose (final concentration $0.3 \% ; 10 \mathrm{ml}$ ) and sterile $10 \% \mathrm{~K}_{2} \mathrm{HPO}_{4}$ (final concentration, $0.25 \mathrm{~g} /$ liter; $2.5 \mathrm{ml}$ ) were added to 1 liter of sterile medium that was cooled to ambient temperature (final $\mathrm{pH}$ of 6.6). Broth $(20 \mathrm{ml})$ was dispensed into sterile disposable petri dishes $(15 \times 100 \mathrm{~mm})$, and a conidium 
suspension $(0.5 \mathrm{ml})$, containing approximately 1 to $2 \times 10^{7}$ conidia per $\mathrm{ml}$, was added to each dish. Dishes were placed at $20^{\circ} \mathrm{C}$ in the dark, and, after 3 days, the mycelium cultures were harvested. Mycelium mats were washed with sterile, distilled water and blotted to remove excess liquid. For each isolate, a volume of 300 to $500 \mu \mathrm{l}$ of mycelium was placed in a sterile microcentrifuge tube, and the tubes were stored at $-80^{\circ} \mathrm{C}$.
DNA extraction. The procedure for extracting DNA was modified from the method of Möller et al. (27). Frozen mycelia were thawed, and the mats were ground with a mortar and pestle in liquid nitrogen. The powdered mycelium was added to sterile 1.5-ml microcentrifuge tubes containing $500 \mu \mathrm{l}$ of TES extraction buffer (100 mM Tris, $\mathrm{pH} 8 ; 10 \mathrm{mM}$ EDTA, pH 8; 2\% sodium dodecyl sulfate [SDS]). RNase A (stock $=10 \mathrm{mg} / \mathrm{ml}$; Sigma BioSciences) was

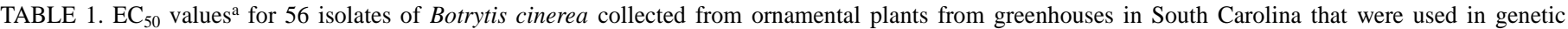
analyses

\begin{tabular}{|c|c|c|c|c|c|c|c|}
\hline \multirow[b]{2}{*}{$\underline{\text { Isolate }}$} & \multicolumn{2}{|l|}{ Source } & \multirow[b]{2}{*}{ Phenotype $^{\mathrm{b}}$} & \multicolumn{2}{|c|}{ Thiophanate-methyl } & \multicolumn{2}{|c|}{ Vinclozolin } \\
\hline & Host plant and organ & County & & $\mathrm{EC}_{50}$-germ & $\mathrm{EC}_{50}$-growth & $\mathrm{EC}_{50}$-germ & $\mathrm{EC}_{50}$-growth \\
\hline$A-2-b$ & Petunia flower & Georgetown & $\mathrm{S}^{\mathrm{T}} \mathrm{S}^{\mathrm{V}}$ & 0.48 & 0.10 & 2.52 & 0.26 \\
\hline A-7-b & Geranium flower & Georgetown & $\mathrm{R}^{\mathrm{T}} \mathrm{S}^{\mathrm{V}}$ & $>500$ & $>500$ & 1.01 & 0.25 \\
\hline A-8-a & Impatiens leaf & Georgetown & $\mathrm{S}^{\mathrm{T}} \mathrm{R}^{\mathrm{V}}$ & 0.40 & 0.13 & 500 & 1.85 \\
\hline B-14-b & Pansy flower & Saluda & $\mathrm{S}^{\mathrm{T}} \mathrm{S}^{\mathrm{V}}$ & 1.06 & 0.08 & 2.21 & 0.25 \\
\hline B-5-b & Poinsettia bract & Saluda & $\mathrm{R}^{\mathrm{T}} \mathrm{R}^{\mathrm{V}}$ & $>500$ & $>500$ & $>500$ & 21.08 \\
\hline B-9-b & Poinsettia leaf & Saluda & $\mathrm{R}^{\mathrm{T}} \mathrm{S}^{\mathrm{V}}$ & $>500$ & $>500$ & 0.51 & 0.22 \\
\hline BT-3-b & Geranium flower & Richland & $\mathrm{S}^{\mathrm{T}} \mathrm{R}^{\mathrm{V}}$ & 2.35 & 0.33 & $>500$ & 1.68 \\
\hline BT-4-a & Geranium leaf & Richland & $\mathrm{R}^{\mathrm{T}} \mathrm{S}^{\mathrm{V}}$ & $>500$ & $>500$ & 0.89 & 0.16 \\
\hline BU-3-b & Begonia leaf & Charleston & $\mathrm{R}^{\mathrm{T}} \mathrm{R}^{\mathrm{V}}$ & $>500$ & $>500$ & $>500$ & 1.90 \\
\hline BU-5-a & Impatiens flower & Charleston & $\mathrm{R}^{\mathrm{T}} \mathrm{S}^{\mathrm{V}}$ & $>500$ & $>500$ & 0.81 & 0.21 \\
\hline BW-1-a & Geranium leaf & Charleston & $\mathrm{R}^{\mathrm{T}} \mathrm{S}^{\mathrm{V}}$ & $>500$ & $>500$ & 1.28 & 0.27 \\
\hline BW-1-b & Geranium leaf & Charleston & $\mathrm{R}^{\mathrm{T}} \mathrm{R}^{\mathrm{V}}$ & $>500$ & $>500$ & $>500$ & 3.14 \\
\hline BW-3-b & Geranium flower & Charleston & $\mathrm{S}^{\mathrm{T}} \mathrm{S}^{\mathrm{V}}$ & 0.63 & 0.07 & 0.87 & 0.03 \\
\hline C-3 & Camellia flower & Berkeley & $\mathrm{R}^{\mathrm{T}} \mathrm{S}^{\mathrm{V}}$ & $>500$ & $>500$ & 1.87 & 0.27 \\
\hline CC-4-a & Begonia leaf & Charleston & $\mathrm{S}^{\mathrm{T}} \mathrm{R}^{\mathrm{V}}$ & 0.74 & 0.05 & $>500$ & 1.11 \\
\hline CC-5-a & Geranium leaf & Charleston & $\mathrm{R}^{\mathrm{T}} \mathrm{S}^{\mathrm{V}}$ & $>500$ & $>500$ & 0.87 & 0.20 \\
\hline CC-6-a & Geranium flower & Charleston & $\mathrm{R}^{\mathrm{T}} \mathrm{R}^{\mathrm{V}}$ & $>500$ & $>500$ & $>500$ & 1.98 \\
\hline CC-6-b & Geranium flower & Charleston & $\mathrm{S}^{\mathrm{T}} \mathrm{S}^{\mathrm{V}}$ & 0.52 & 0.10 & 1.40 & 0.20 \\
\hline CG-1-b & Geranium leaf & Colleton & $\mathrm{R}^{\mathrm{T}} \mathrm{R}^{\mathrm{V}}$ & $>500$ & $>500$ & $>500$ & 1.03 \\
\hline CG-2-a & Ivy-geranium leaf & Colleton & $\mathrm{S}^{\mathrm{T}} \mathrm{S}^{\mathrm{V}}$ & 1.87 & 0.09 & 0.93 & 0.21 \\
\hline $\mathrm{CH}-5-\mathrm{a}$ & Geranium leaf & Charleston & $\mathrm{S}^{\mathrm{T}} \mathrm{S}^{\mathrm{V}}$ & 0.22 & 0.15 & 1.40 & 0.28 \\
\hline $\mathrm{CH}-5-\mathrm{b}$ & Geranium leaf & Charleston & $\mathrm{R}^{\mathrm{T}} \mathrm{S}^{\mathrm{V}}$ & $>500$ & $>500$ & 0.72 & 0.36 \\
\hline $\mathrm{CH}-6-\mathrm{b}$ & Geranium leaf & Charleston & $\mathrm{S}^{\mathrm{T}} \mathrm{R}^{\mathrm{V}}$ & 0.88 & 0.08 & $>500$ & 2.04 \\
\hline CL-1-b & Azalea flower & Oconee & $\mathrm{S}^{\mathrm{T}} \mathrm{S}^{\mathrm{V}}$ & 0.95 & 0.10 & 2.70 & 0.35 \\
\hline CN-1-a & Gerbera daisy leaf & Horry & $\mathrm{S}^{\mathrm{T}} \mathrm{S}^{\mathrm{V}}$ & 0.53 & 0.16 & 1.65 & 0.46 \\
\hline $\mathrm{CN}-2-\mathrm{b}$ & Gerbera daisy flower & Horry & $\mathrm{R}^{\mathrm{T}} \mathrm{R}^{\mathrm{V}}$ & $>500$ & $>500$ & $>500$ & 1.11 \\
\hline DC-5 & Geranium flower & Washington, $\mathrm{DC}^{\mathrm{c}}$ & $\mathrm{S}^{\mathrm{T}} \mathrm{S}^{\mathrm{V}}$ & 0.23 & 0.14 & 1.62 & 0.07 \\
\hline DD-10-a & Calendula flower & Newberry & $\mathrm{S}^{\mathrm{T}} \mathrm{S}^{\mathrm{V}}$ & 1.05 & 0.05 & 1.34 & 0.28 \\
\hline DD-4-b & Geranium leaf & Newberry & $\mathrm{R}^{\mathrm{T}} \mathrm{R}^{\mathrm{V}}$ & $>500$ & $>500$ & $>500$ & 2.17 \\
\hline DD-9-b & Cosmos flower & Newberry & $\mathrm{R}^{\mathrm{T}} \mathrm{S}^{\mathrm{V}}$ & $>500$ & $>500$ & 1.55 & 0.26 \\
\hline FL-4-b & Geranium leaf & Florence & $\mathrm{S}^{\mathrm{T}} \mathrm{S}^{\mathrm{V}}$ & 2.07 & 0.36 & 0.85 & 0.12 \\
\hline GA-1 & Chrysanthemum leaf & Dorchester & $\mathrm{S}^{\mathrm{T}} \mathrm{S}^{\mathrm{V}}$ & 0.89 & 0.30 & 2.93 & 0.26 \\
\hline GG-4-a & Pansy flower & Georgetown & $\mathrm{R}^{\mathrm{T}} \mathrm{R}^{\mathrm{V}}$ & $>500$ & $>500$ & $>500$ & 1.81 \\
\hline GG-4-b & Pansy flower & Georgetown & $\mathrm{R}^{\mathrm{T}} \mathrm{S}^{\mathrm{V}}$ & $>500$ & $>500$ & 2.57 & 0.34 \\
\hline GO-1-b & Geranium leaf & Marion & $\mathrm{R}^{\mathrm{T}} \mathrm{R}^{\mathrm{V}}$ & $>500$ & $>500$ & $>500$ & 1.52 \\
\hline GO-2-a & Begonia flower & Marion & $\mathrm{R}^{\mathrm{T}} \mathrm{S}^{\mathrm{V}}$ & $>500$ & $>500$ & 2.11 & 0.29 \\
\hline $\mathrm{H}-3-\mathrm{a}$ & Geranium flower & Dorchester & $\mathrm{S}^{\mathrm{T}} \mathrm{R}^{\mathrm{V}}$ & 0.43 & 0.06 & $>500$ & 1.65 \\
\hline $\mathrm{H}-3-\mathrm{b}$ & Geranium flower & Dorchester & $\mathrm{R}^{\mathrm{T}} \mathrm{S}^{\mathrm{V}}$ & $>500$ & $>500$ & 0.75 & 0.24 \\
\hline H-4-b & Begonia flower & Dorchester & $\mathrm{S}^{\mathrm{T}} \mathrm{S}^{\mathrm{V}}$ & 2.22 & 0.07 & 1.17 & 0.19 \\
\hline $\mathrm{HC}-1-\mathrm{b}$ & Artemesia leaf & Calhoun & $\mathrm{R}^{\mathrm{T}} \mathrm{R}^{\mathrm{V}}$ & $>500$ & $>500$ & $>500$ & 1.25 \\
\hline $\mathrm{HC}-2-\mathrm{a}$ & Impatiens flower & Calhoun & $\mathrm{S}^{\mathrm{T}} \mathrm{S}^{\mathrm{V}}$ & 0.81 & 0.09 & 1.17 & 0.24 \\
\hline HH-5-a & Petunia flower & Richland & $\mathrm{S}^{\mathrm{T}} \mathrm{S}^{\mathrm{V}}$ & 0.10 & 0.12 & 2.64 & 0.16 \\
\hline HH-9-b & Begonia flower & Richland & $\mathrm{R}^{\mathrm{T}} \mathrm{S}^{\mathrm{V}}$ & $>500$ & $>500$ & 1.16 & 0.18 \\
\hline HK-1-b & Geranium leaf & Lexington & $\mathrm{R}^{\mathrm{T}} \mathrm{S}^{\mathrm{V}}$ & $>500$ & $>500$ & 1.07 & 0.25 \\
\hline HK-3-a & Geranium leaf & Lexington & $\mathrm{R}^{\mathrm{T}} \mathrm{S}^{\mathrm{V}}$ & $>500$ & $>500$ & 1.30 & 0.19 \\
\hline HL-7-1 & Poinsettia leaf & Oconee & $\mathrm{S}^{\mathrm{T}} \mathrm{S}^{\mathrm{V}}$ & 0.54 & 0.08 & 3.51 & 0.31 \\
\hline MD-3-a & Impatiens flower & Georgetown & $\mathrm{R}^{\mathrm{T}} \mathrm{R}^{\mathrm{V}}$ & $>500$ & $>500$ & $>500$ & 1.76 \\
\hline MD-6-a & Geranium flower & Georgetown & $\mathrm{S}^{\mathrm{T}} \mathrm{S}^{\mathrm{V}}$ & 0.48 & 0.16 & 2.95 & 0.20 \\
\hline PB-1-a & Geranium leaf & Richland & $\mathrm{R}^{\mathrm{T}} \mathrm{R}^{\mathrm{V}}$ & $>500$ & $>500$ & $>500$ & 1.31 \\
\hline PL-4-b & Snapdragon flower & Richland & $\mathrm{S}^{\mathrm{T}} \mathrm{S}^{\mathrm{V}}$ & 1.12 & 0.10 & 2.21 & 0.27 \\
\hline PP-4-b & Oregano leaf & Charleston & $\mathrm{S}^{\mathrm{T}} \mathrm{S}^{\mathrm{V}}$ & 0.43 & 0.10 & 2.66 & 0.21 \\
\hline PS-4-b & Geranium flower & Colleton & $\mathrm{R}^{\mathrm{T}} \mathrm{R}^{\mathrm{V}}$ & $>500$ & $>500$ & $>500$ & 1.97 \\
\hline PW-6-b & New Guinea impatiens leaf & Richland & $\mathrm{R}^{\mathrm{T}} \mathrm{R}^{\mathrm{V}}$ & $>500$ & $>500$ & $>500$ & 1.41 \\
\hline S-1-b & Poinsettia leaf & York & $\mathrm{R}^{\mathrm{T}} \mathrm{R}^{\mathrm{V}}$ & $>500$ & $>500$ & $>500$ & 11.90 \\
\hline S-8-a & Cattlea petal & York & $\mathrm{R}^{\mathrm{T}} \mathrm{S}^{\mathrm{V}}$ & $>500$ & $>500$ & 1.72 & 0.29 \\
\hline SI-4-b & Begonia leaf & Charleston & $\mathrm{R}^{\mathrm{T}} \mathrm{R}^{\mathrm{V}}$ & $>500$ & $>500$ & $>500$ & 1.37 \\
\hline UG-2 & Geranium leaf & Greenville & $\mathrm{S}^{\mathrm{T}} \mathrm{S}^{\mathrm{V}}$ & 1.83 & 0.07 & 0.98 & 0.34 \\
\hline UG-9 & Geranium flower & Greenville & $\mathrm{R}^{\mathrm{T}} \mathrm{R}^{\mathrm{V}}$ & $>500$ & $>500$ & $>500$ & 1.30 \\
\hline WD-1 & Cherry tomato fruit & Oconee & $\mathrm{R}^{\mathrm{T}} \mathrm{R}^{\mathrm{V}}$ & $>500$ & $>500$ & $>500$ & 1.60 \\
\hline
\end{tabular}

${ }^{a} \mathrm{EC}_{50}$ values were the effective concentrations of fungicides that inhibited conidium germination (EC ${ }_{50}$-germ) or mycelium growth (EC ${ }_{50}$-growth) by $50 \%$.

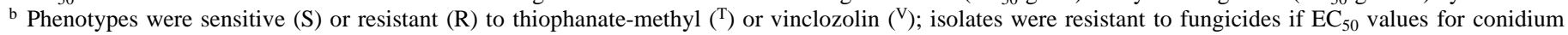
germination or mycelium growth were $\geq 5 \mu \mathrm{g} / \mathrm{ml}$ or $\geq 1 \mu \mathrm{g} / \mathrm{ml}$, respectively.

c Isolate collected in Washington, DC. 
dispensed into each suspension for a final concentration of $50 \mu \mathrm{g} / \mathrm{ml}$, and tubes were held at $37^{\circ} \mathrm{C}$ for $30 \mathrm{~min}$. Proteinase $\mathrm{K}$ (stock = $10 \mathrm{mg} / \mathrm{ml}$; Sigma BioSciences) was added to each suspension to give a final concentration of $100 \mu \mathrm{g} / \mathrm{ml}$, and suspensions were held at $60^{\circ} \mathrm{C}$ for $60 \mathrm{~min}$. Two hundred microliters of $5 \mathrm{M} \mathrm{NaCl}$ and $70 \mu \mathrm{l}$ of warm $10 \%$ CTAB (hexade-cyltrimethyl-ammonium bromide) (Sigma BioSciences) were added to each solution, and solutions were held at $65^{\circ} \mathrm{C}$ for $10 \mathrm{~min}$. An aliquot of $700 \mu \mathrm{l}$ of chloroform:isoamyl alcohol (24:1) was added to each tube, and tubes were placed on ice for $30 \mathrm{~min}$. Tubes with solutions were centrifuged at $13,000 \mathrm{rpm}$ for $10 \mathrm{~min}$. The upper phase was transferred to a new tube, and $225 \mu \mathrm{l}$ of $5 \mathrm{M} \mathrm{NH}_{4} \mathrm{OAc}$ (1.2 M final concentration) was added. Solutions were mixed gently and placed on ice for at least $30 \mathrm{~min}$. To precipitate DNA, $0.55 \times(510 \mu \mathrm{l})$ of cold isopropanol was added to each tube, and tubes were centrifuged at 13,000 rpm for 5 min. DNA pellets were washed once with $70 \%$ ethanol containing $10 \mathrm{mM} \mathrm{NH}_{4} \mathrm{OAc}$ and once with $70 \%$ ethanol and were suspended in 200 to $300 \mu \mathrm{l}$ of nucleasefree water (Promega Corp., Madison, WI). For each isolate, DNA was extracted independently from two cultures and used as template DNA for separate RAPD fingerprint replicate sets.

Primers. An initial screen of 130 primers against 12 isolates of $B$. cinerea ( 3 isolates of each phenotype) was conducted with Operon 10-mer oligonucleotide kits OP-A, -B, -C, -D, -K, and -T (Operon Technologies Inc., Alameda, CA) and 10 laboratory primers (courtesy of Y. Wang and R. A. Dean, Genomics Institute, Clemson University, Clemson, SC) to search for polymorphisms. Based on this screen, 12 primers were selected for use in this study: OPB-9, -11, -19, and -20, OPC-3, -9, and -14, OPD-4, -6, -9, and -10 , and laboratory primer no. 162 ( $5^{\prime}$ AACTTACCGC $\left.3^{\prime}\right)$.

RAPD-Polymerase chain reaction procedures. DNA solutions were quantified by fluorometry (TKO 100, Hoefer Scientific Instruments, San Francisco, CA) and diluted in nucleasefree water to working concentrations of $3.33 \mathrm{ng} / \mu \mathrm{l}$ (i.e., $500 \mathrm{ng} / 150 \mu \mathrm{l}$ of water). Two microliters of template DNA (or water as a negative control) was dispensed into $0.2-\mathrm{ml}$ polymerase chain reaction (PCR) tubes (Corning, Corning, NY). A PCR reaction mixture was made for each individual primer (all constituents of the mixtures except primers were purchased from Promega Corp.) and contained $11.8 \mu \mathrm{l}$ of nuclease-free water, $2.0 \mu \mathrm{l}$ of $10 \times T f l$ reaction buffer, $1.2 \mu \mathrm{l}$ of $\mathrm{MgSO}_{4}(25 \mathrm{mM}), 0.8 \mu \mathrm{l}$ of dNTPs (2.5 mM each), $2.0 \mu \mathrm{l}$ of 10-base primer $(6.25 \mu \mathrm{M})$, and $0.2 \mu \mathrm{l}$ of $T f l$ polymerase (approximately 1.0 unit). Eighteen microliters was pipetted into each PCR tube containing $2 \mu$ of template DNA. The tubes containing $20 \mu \mathrm{l}$ were placed in a Amplitron II thermocycler (Barnstead/Thermolyne Corp., Dubuque, IA) with an initial denaturing temperature of $94^{\circ} \mathrm{C}$ for $4 \mathrm{~min}$. Each cycle was programmed as follows: (i) fast ramp to $94^{\circ} \mathrm{C}$; (ii) $94^{\circ} \mathrm{C}$ (15 s hold); (iii) fast ramp to $44^{\circ} \mathrm{C}$; (iv) $44^{\circ} \mathrm{C}$ (30 s hold); (v) $60 \mathrm{~s}$ ramp to $72^{\circ} \mathrm{C}$; and (vi) $72^{\circ} \mathrm{C}(60 \mathrm{~s}$ hold). After 45 cycles, a final extension temperature of $72^{\circ} \mathrm{C}$ for $5 \mathrm{~min}$ was followed by a dwell temperature of $4^{\circ} \mathrm{C}$.

RAPD fingerprints. Gels $(100 \times 250 \mathrm{~mm})$ were prepared with $1.4 \%$ agarose (Mallinckrodt Baker Inc., Paris, KY) in $100 \mathrm{ml}$ of $0.5 \times$ Tris-boric acid-EDTA (TBE) buffer (33), and wells were formed with a 40 -well comb (3 mm per lane). Gels were placed in an electrophoresis apparatus containing $0.5 \times$ TBE. Each PCR reaction was provided with $2 \mu \mathrm{l}$ of $10 \times$ gel-loading buffer, and $20 \mu \mathrm{l}$ were loaded into each well. Each of three lanes was loaded with approximately $1 \mathrm{ng}$ of a 123-bp DNA ladder (Gibco BRL, Life Technologies Inc., Gaithersburg, MD). Electrophoresis was carried out for $3 \mathrm{~h}$ at $70 \mathrm{~V}$ and gels were stained for $25 \mathrm{~min}$ in $200 \mathrm{ml}$ of $0.5 \times \mathrm{TBE}$ with $4 \mu \mathrm{l}$ of ethidium bromide $(10 \mathrm{mg} / \mathrm{ml})$. Gels were washed in water for 45 min before photographing with type 667 (positive) film and type 665 (positive/negative) film with a No. 16A Wratten filter (Polaroid Corp., Cambridge, MA) and UV light from a transilluminator.

Fingerprint analyses. In all, five RAPD fingerprint sets were generated for this study. Each set contained 12 gels -1 for each of the selected primers. The 56 greenhouse isolates were separated into 2 sets of 20 and 21 isolates, with the remaining 15 isolates used in each set. In this way, genetic relationships identified for one set of isolates could be confirmed and validated by independent analysis of the second set of isolates. Therefore, Greenhouse $(\mathrm{GH})$ set 1 contained 35 greenhouse isolates: $10 \mathrm{~S}^{\mathrm{T}} \mathrm{S}^{\mathrm{V}}$ isolates, $10 \mathrm{R}^{\mathrm{T}} \mathrm{R}^{\mathrm{V}}, 10 \mathrm{R}^{\mathrm{T}} \mathrm{S}^{\mathrm{V}}$, and $5 \mathrm{~S}^{\mathrm{T}} \mathrm{R}^{\mathrm{V}}$; and $\mathrm{GH}$ set 2 contained 36 isolates: $11 \mathrm{~S}^{\mathrm{T}} \mathrm{S}^{\mathrm{V}}, 11 \mathrm{R}^{\mathrm{T}} \mathrm{R}^{\mathrm{V}}, 9 \mathrm{R}^{\mathrm{T}} \mathrm{S}^{\mathrm{V}}$, and $5 \mathrm{~S}^{\mathrm{T}} \mathrm{R}^{\mathrm{V}}$. The 15 isolates that were common to both sets included 4 that were sensitive to both fungicides, 3 that were resistant to both fungicides, 3 that were resistant to thiophanate-methyl and sensitive to vinclozolin, and 5 that were sensitive to thiophanate-methyl and resistant to vinclozolin.

To further study genetic variation and the relationships identified among the greenhouse isolates, 82 isolates (57 variant isolates, 14 sensitive greenhouse isolates that were parents of the variant isolates, and 11 resistant greenhouse isolates) were analyzed as 3 RAPD fingerprint sets, with 36 isolates used in each set. Variant set 1 contained 32 variant and $4 \mathrm{~S}^{\mathrm{T}} \mathrm{S}^{\mathrm{V}}$ parent isolates; Variant set 2 contained 24 variant, $6 \mathrm{~S}^{\mathrm{T}} \mathrm{S}^{\mathrm{V}}$ parent isolates, $4 \mathrm{R}^{\mathrm{T}} \mathrm{R}^{\mathrm{V}}$, and $2 \mathrm{R}^{\mathrm{T}} \mathrm{S}^{\mathrm{V}}$ greenhouse isolates; and Variant set 3 contained 23 variant isolates, $8 \mathrm{~S}^{\mathrm{T}} \mathrm{S}^{\mathrm{V}}$ parent, and $5 \mathrm{~S}^{\mathrm{T}} \mathrm{R}^{\mathrm{V}}$ greenhouse isolates. Some isolates were used in more than one set. A single trial consisted of running the 12 gels for one fingerprint set. Each trial was conducted twice, and the data initially were analyzed separately. Data for the two trials of each fingerprint set were nearly identical so they were combined and analyzed together. Binary matrices were constructed according to the presence or absence of bands. Cluster analyses were performed by the unweighted pair group method using arithmetic average (UPGMA) $(7,38)$ with the software program PAUP* (Phylogenetic Analysis Using Parsimony and other methods; version 4.0b2, Sinauer Associates, Sunderland, MA). Distances were measured by mean character differences. Bootstrap analyses of 500 replicates by full heuristic general searches were conducted to evaluate the confidence level of cluster patterns. Consensus cladograms were constructed based on the $50 \%$ majority rule. Cladograms were labeled above the branches with mean character difference values and bootstrap confidence values, listed in parentheses.

\section{RESULTS}

Greenhouse isolates. In all, 56 isolates of $B$. cinerea collected from ornamental plants were subjected to RAPD fingerprint analyses to examine the genetic variation among isolates with different sensitivities to thiophanate-methyl and vinclozolin. To verify relationships and establish reproducibility, isolates were analyzed as 2 independent sets with 15 isolates common to both sets. Both sets produced similar results. Relationships among isolates with the same phenotypes were consistent in both fingerprint sets of greenhouse isolates, and the 15 isolates that were common to both fingerprint sets clustered similarly in the 2 sets. When clusters with high bootstrap values occurred, they were composed of isolates with the same phenotype. In GH set 1, 197 characters were informative and were used to construct a cladogram detailing relationships among isolates (Fig. 1A); in GH set 2, 179 characters were used to construct a cladogram (Fig. 1B). One primer, OPD-6, gave a strong amplification product of approximately $450 \mathrm{bp}$ in all isolates of $B$. cinerea examined. This has been suggested as a possible marker for $B$. cinerea $(20,39)$.

Ten and eleven isolates sensitive to both fungicides $\left(\mathrm{S}^{\mathrm{T}} \mathrm{S}^{\mathrm{V}}\right)$ were included in GH sets 1 and 2, respectively, with four isolates (B14-b, DC-5, GA-1, and HL-7-1) common to both sets. In GH set 1 (Fig 1A), 6 of 10 sensitive isolates were clustered together, with a bootstrap value of $91 \%$. These six isolates included three (B-14-b, GA-1, and HL-7-1) of the four sensitive isolates that were common to both fingerprint sets. Two other $\mathrm{S}^{\mathrm{T}} \mathrm{S}^{\mathrm{V}}$ isolates clustered together (DC-5 and UG-2), and the remaining two $\mathrm{S}^{\mathrm{T}} \mathrm{S}^{\mathrm{V}}$ isolates (BW-3-b and CC-6-b) 
did not cluster with any other isolate. In GH set 2 (Fig. 1B), 9 of 11 $\mathrm{S}^{\mathrm{T}} \mathrm{S}^{\mathrm{V}}$ isolates formed a single large cluster-including B-14-b, GA-1, and HL-7-1-and the other $2 \mathrm{~S}^{\mathrm{T}} \mathrm{S}^{\mathrm{V}}$ isolates were not closely associated with other $\mathrm{S}^{\mathrm{T}} \mathrm{S}^{\mathrm{V}}$ isolates in the set.

In contrast, in both $\mathrm{GH}$ sets 1 and 2, isolates that were resistant to one or both fungicides either did not cluster with other isolates or clustered with other resistant isolates of the same phenotype. In GH set 1 (Fig. 1A), the following clusters of similar phenotypes occurred: $\mathrm{R}^{\mathrm{T}} \mathrm{S}^{\mathrm{V}}$ : HK-3-a and HH-9-b, H-3-b and A-7-b; $S^{\mathrm{T}} \mathrm{R}^{\mathrm{V}}$ : CH-6-b and BT-3-b, A-8-a and CC-4-a; and $\mathrm{R}^{\mathrm{T}} \mathrm{R}^{\mathrm{V}}$ : BW-1-b and B-5-b, UG-9 and GO-1-b, CN-2-b and CG-1-b. The remaining isolates did not cluster. In GH set 2 (Fig. 1B), the following clusters of resistant isolates occurred: $\mathrm{R}^{\mathrm{T}} \mathrm{S}^{\mathrm{V}}$ : HK-1-b and HH-9-b, C-3 and GG-4b; $\mathrm{S}^{\mathrm{T}} \mathrm{R}^{\mathrm{V}}$ : CC-4-a and A-8-a, BT-3-b and CH-6-b (as in GH set 1); and $\mathrm{R}^{\mathrm{T}} \mathrm{R}^{\mathrm{V}}$ : HC-1-b and PB-1-a, GO-1-b and CC-6-a, BU-3-b and MD-3-a.

Variant isolates. A total of 148 variant isolates resistant to thiophanate-methyl, vinclozolin, or both was selected in the laboratory from $14 \mathrm{~S}^{\mathrm{T}} \mathrm{S}^{\mathrm{V}}$ parents that had been placed on media amended with either thiophanate-methyl or vinclozolin. Of these, 57 variants $\left(R^{T} S^{V}, S^{T} R^{V}\right.$, and $\left.R^{T} R^{V}\right)$ were selected to further study genetic variation and relationships among isolates with known parentage (Table 2). Three RAPD fingerprints sets (Variant sets 1, 2 , and 3) were generated with the 57 variants, 14 parent, and 11 resistant isolates recovered from greenhouses. In all three sets, all isolates had a strong amplification product of approximately $450 \mathrm{bp}$ from reactions primed by OPD-6, which was consistent with results for isolates of $B$. cinerea in GH sets 1 and 2 .

$\mathrm{EC}_{50}$ values for mycelium growth were greater than $500 \mu \mathrm{g}$ of thiophanate-methyl per $\mathrm{ml}$ for all but one of the variants resistant to thiophanate-methyl (Table 2). Variants resistant to thiophanatemethyl and vinclozolin $\left(\mathrm{R}^{\mathrm{T}} \mathrm{R}^{\mathrm{V}}\right)$ had $\mathrm{EC}_{50}$ values ranging from 1.0 to $9.1 \mu \mathrm{g}$ of vinclozolin per ml. Variants resistant to thiophanatemethyl and sensitive to vinclozolin $\left(\mathrm{R}^{\mathrm{T}} \mathrm{S}^{\mathrm{V}}\right)$ had $\mathrm{EC}_{50}$ values ranging from 0.1 to $0.2 \mu \mathrm{g}$ of vinclozolin per ml. Variants sensitive to thiophanate-methyl and resistant to vinclozolin $\left(\mathrm{S}^{\mathrm{T}} \mathrm{R}^{\mathrm{V}}\right)$ had $\mathrm{EC}_{50}$ values ranging from 0.03 to $0.4 \mu \mathrm{g}$ of thiophanate-methyl per $\mathrm{ml}$ and 1.8 to $>100 \mu \mathrm{g}$ of vinclozolin per $\mathrm{ml}$.

Eight parent isolates produced at least one variant isolate resistant to both fungicides $\left(\mathrm{R}^{\mathrm{T}} \mathrm{R}^{\mathrm{V}}\right)$ even though parent isolates were exposed to only one fungicide in the selection procedure. Parent isolate $\mathrm{CH}-5$-a produced 29 clonal derivatives on thiophanatemethyl-amended medium and 28 clonal derivatives on vinclozolin-amended medium in two independent selection procedures. All of these isolates were resistant to both fungicides, except one $\mathrm{R}^{\mathrm{T}} \mathrm{S}^{\mathrm{V}}$ variant selected on thiophanate-methyl-amended medium. Nine of the variants from parent $\mathrm{CH}-5$-a were used in this study.

Variant set 1. RAPD fingerprints were made with 36 isolates$4 S^{\mathrm{T}} S^{\mathrm{V}}$ parent and 32 resistant variants (i.e., $24 \mathrm{R}^{\mathrm{T}} \mathrm{R}^{\mathrm{V}}, 5 \mathrm{R}^{\mathrm{T}} \mathrm{S}^{\mathrm{V}}$, and $3 S^{T} R^{v}$ ). A cladogram (Fig. 2A) was constructed from a data set with 169 informative characters. The four $\mathrm{S}^{\mathrm{T}} \mathrm{S}^{\mathrm{V}}$ parent isolates and three $S^{T} R^{V}$ variants, all from parent isolate $\mathrm{HH}-5$-a, clustered with a bootstrap value of $100 \%$. In contrast, variants resistant to thiophanate-methyl (either $\mathrm{R}^{\mathrm{T}} \mathrm{R}^{\mathrm{V}}$ or $\mathrm{R}^{\mathrm{T}} \mathrm{S}^{\mathrm{V}}$ ) clustered independently from their $\mathrm{S}^{\mathrm{T}} \mathrm{S}^{\mathrm{V}}$ parent isolates-including the only $\mathrm{R}^{\mathrm{T}} \mathrm{R}^{\mathrm{V}}$ clonal derivative of HH-5-a. In addition, most variants derived from the same parent with the same phenotype clustered together with high bootstrap values, but these variants did not cluster with clonal derivatives from the same parent with different phenotypes. RAPD profiles of all eight $\mathrm{R}^{\mathrm{T}} \mathrm{R}^{\mathrm{V}}$ clonal derivatives from parent $\mathrm{CH}-5$-a were nearly identical and clustered with a bootstrap value of $100 \%$. However, variant $\mathrm{CH}-5-\mathrm{a} / \mathrm{T} 6$, was $\mathrm{R}^{\mathrm{T}} \mathrm{S}^{\mathrm{V}}$ and was the only clonal derivative of $\mathrm{CH}-5$-a that did not cluster with the $\mathrm{R}^{\mathrm{T}} \mathrm{R}^{\mathrm{V}}$ variants. All four $\mathrm{R}^{\mathrm{T}} \mathrm{S}^{\mathrm{V}}$ clonal derivatives from parent FL-4$\mathrm{b}$ clustered together with a bootstrap value of $100 \%$; these four isolates clustered independently, however, from the seven $R^{T} R^{V}$ clonal derivatives from this same parent.

Variant set 2. RAPD fingerprints from a second set of variant isolates were analyzed to further investigate the genetic relation-
TABLE 2. Phenotypes of and $\mathrm{EC}_{50}$ values for thiophanate-methyl and vinclozolin for 57 variant isolates of Botrytis cinerea ${ }^{\mathrm{a}}$

\begin{tabular}{|c|c|c|c|c|}
\hline \multicolumn{3}{|c|}{ Isolate } & \multicolumn{2}{|c|}{$\mathrm{EC}_{50^{-}}$growth $^{\mathrm{b}}$} \\
\hline No. ${ }^{c}$ & Phenotype $^{\mathrm{d}}$ & Year $^{\mathrm{e}}$ & Thiophanate-methyl & Vinclozolin \\
\hline B-14-b/T1 & $\mathrm{R}^{\mathrm{T}} \mathrm{R}^{\mathrm{V}}$ & 1997 & $>500$ & 1.1 \\
\hline B-14-b/T2 & $\mathrm{R}^{\mathrm{T}} \mathrm{R}^{\mathrm{V}}$ & 1997 & $>500$ & 3.7 \\
\hline B-14-b/T3 & $\mathrm{R}^{\mathrm{T}} \mathrm{R}^{\mathrm{V}}$ & 1997 & $>500$ & 9.1 \\
\hline B-14-b/T4 & $\mathrm{R}^{\mathrm{T}} \mathrm{R}^{\mathrm{V}}$ & 1997 & $>500$ & 7.7 \\
\hline B-14-b/V1 & $\mathrm{R}^{\mathrm{T}} \mathrm{R}^{\mathrm{V}}$ & 1997 & $>500$ & 2.3 \\
\hline B-14-b/V2 & $\mathrm{R}^{\mathrm{T}} \mathrm{R}^{\mathrm{V}}$ & 1997 & $>500$ & 4.2 \\
\hline B-14-b/V3 & $\mathrm{R}^{\mathrm{T}} \mathrm{R}^{\mathrm{V}}$ & 1997 & $>500$ & 3.2 \\
\hline B-14-b/V4 & $\mathrm{R}^{\mathrm{T}} \mathrm{R}^{\mathrm{V}}$ & 1997 & $>500$ & 3.2 \\
\hline BW-3-b/V1 & $\mathrm{S}^{\mathrm{T}} \mathrm{R}^{\mathrm{V}}$ & 1997 & $<0.1$ & $>100$ \\
\hline BW-3-b/Va & $\mathrm{S}^{\mathrm{T}} \mathrm{R}^{\mathrm{V}}$ & 1998 & 0.1 & 2.2 \\
\hline $\mathrm{BW}-3-\mathrm{b} / \mathrm{Vb}$ & $\mathrm{S}^{\mathrm{T}} \mathrm{R}^{\mathrm{V}}$ & 1998 & 0.2 & 25.2 \\
\hline CC-6-b/T1 & $\mathrm{R}^{\mathrm{T}} \mathrm{R}^{\mathrm{V}}$ & 1997 & $>500$ & 1.6 \\
\hline CC-6-b/T2 & $\mathrm{R}^{\mathrm{T}} \mathrm{R}^{\mathrm{V}}$ & 1997 & $>500$ & 4.5 \\
\hline CC-6-b/V1 & $\mathrm{R}^{\mathrm{T}} \mathrm{R}^{\mathrm{V}}$ & 1997 & $>500$ & 1.2 \\
\hline CH-5-a/T1 & $\mathrm{R}^{\mathrm{T}} \mathrm{R}^{\mathrm{V}}$ & 1997 & $>500$ & 1.1 \\
\hline CH-5-a/T6 & $\mathrm{R}^{\mathrm{T}} \mathrm{S}^{\mathrm{V}}$ & 1997 & $>500$ & 0.1 \\
\hline CH-5-a/T20 & $\mathrm{R}^{\mathrm{T}} \mathrm{R}^{\mathrm{V}}$ & 1997 & $>500$ & 1.5 \\
\hline $\mathrm{CH}-5-\mathrm{a} / \mathrm{Tb}$ & $\mathrm{R}^{\mathrm{T}} \mathrm{R}^{\mathrm{V}}$ & 1998 & $>500$ & 1.5 \\
\hline $\mathrm{CH}-5-\mathrm{a} / \mathrm{Tj}$ & $\mathrm{R}^{\mathrm{T}} \mathrm{R}^{\mathrm{V}}$ & 1998 & $>500$ & 1.5 \\
\hline CH-5-a/V1 & $\mathrm{R}^{\mathrm{T}} \mathrm{R}^{\mathrm{V}}$ & 1997 & $>500$ & 1.8 \\
\hline CH-5-a/V9 & $\mathrm{R}^{\mathrm{T}} \mathrm{R}^{\mathrm{V}}$ & 1997 & $>500$ & 1.6 \\
\hline $\mathrm{CH}-5-\mathrm{a} / \mathrm{Va}$ & $\mathrm{R}^{\mathrm{T}} \mathrm{R}^{\mathrm{V}}$ & 1998 & $>500$ & 1.6 \\
\hline CH-5-a/Vh & $\mathrm{R}^{\mathrm{T}} \mathrm{R}^{\mathrm{V}}$ & 1998 & $>500$ & 1.3 \\
\hline DC-5/V1 & $\mathrm{R}^{\mathrm{T}} \mathrm{R}^{\mathrm{V}}$ & 1997 & $>500$ & 1.0 \\
\hline DC-5/V2 & $\mathrm{S}^{\mathrm{T}} \mathrm{R}^{\mathrm{V}}$ & 1997 & 0.2 & $>100$ \\
\hline DD-10-a/V1 & $\mathrm{S}^{\mathrm{T}} \mathrm{R}^{\mathrm{V}}$ & 1997 & 0.1 & $>100$ \\
\hline DD-10-a/V2 & $\mathrm{S}^{\mathrm{T}} \mathrm{R}^{\mathrm{V}}$ & 1997 & 0.1 & $>100$ \\
\hline FL-4-b/T1 & $\mathrm{R}^{\mathrm{T}} \mathrm{R}^{\mathrm{V}}$ & 1997 & $>500$ & 1.4 \\
\hline FL-4-b/T2 & $\mathrm{R}^{\mathrm{T}} \mathrm{R}^{\mathrm{V}}$ & 1997 & $>500$ & 1.6 \\
\hline FL-4-b/T3 & $\mathrm{R}^{\mathrm{T}} \mathrm{R}^{\mathrm{V}}$ & 1997 & $>500$ & 1.4 \\
\hline FL-4-b/T4 & $\mathrm{R}^{\mathrm{T}} \mathrm{R}^{\mathrm{V}}$ & 1997 & $>500$ & 1.2 \\
\hline FL-4-b/T5 & $\mathrm{R}^{\mathrm{T}} \mathrm{S}^{\mathrm{V}}$ & 1997 & $>500$ & 0.1 \\
\hline FL-4-b/Tb & $\mathrm{R}^{\mathrm{T}} \mathrm{S}^{\mathrm{V}}$ & 1998 & $>500$ & 0.2 \\
\hline FL-4-b/Tff & $\mathrm{R}^{\mathrm{T}} \mathrm{S}^{\mathrm{V}}$ & 1998 & $>500$ & 0.1 \\
\hline FL-4-b/Tg & $\mathrm{R}^{\mathrm{T}} \mathrm{S}^{\mathrm{V}}$ & 1998 & 241.1 & 0.1 \\
\hline FL-4-b/V1 & $\mathrm{R}^{\mathrm{T}} \mathrm{R}^{\mathrm{V}}$ & 1997 & $>500$ & 1.2 \\
\hline FL-4-b/V3 & $\mathrm{R}^{\mathrm{T}} \mathrm{R}^{\mathrm{V}}$ & 1997 & $>500$ & 1.4 \\
\hline FL-4-b/V4 & $\mathrm{R}^{\mathrm{T}} \mathrm{R}^{\mathrm{V}}$ & 1997 & $>500$ & 3.3 \\
\hline GA-1/T1 & $\mathrm{R}^{\mathrm{T}} \mathrm{S}^{\mathrm{V}}$ & 1997 & $>500$ & 0.1 \\
\hline GA-1/V1 & $\mathrm{S}^{\mathrm{T}} \mathrm{R}^{\mathrm{V}}$ & 1997 & 0.1 & 2.6 \\
\hline GA-1/V2 & $\mathrm{R}^{\mathrm{T}} \mathrm{R}^{\mathrm{V}}$ & 1997 & $>500$ & 1.2 \\
\hline GA-1/Va & $\mathrm{S}^{\mathrm{T}} \mathrm{R}^{\mathrm{V}}$ & 1998 & 0.1 & $>100$ \\
\hline GA-1/Vb & $\mathrm{S}^{\mathrm{T}} \mathrm{R}^{\mathrm{V}}$ & 1998 & 0.2 & $>100$ \\
\hline $\mathrm{H}-4-\mathrm{b} / \mathrm{T} 1$ & $\mathrm{R}^{\mathrm{T}} \mathrm{S}^{\mathrm{V}}$ & 1997 & $>500$ & 0.1 \\
\hline $\mathrm{HC}-2-\mathrm{a} / \mathrm{Va}$ & $\mathrm{S}^{\mathrm{T}} \mathrm{R}^{\mathrm{V}}$ & 1998 & 0.1 & 1.8 \\
\hline $\mathrm{HC}-2-\mathrm{a} / \mathrm{Vb}$ & $\mathrm{S}^{\mathrm{T}} \mathrm{R}^{\mathrm{V}}$ & 1998 & 0.2 & 2.1 \\
\hline HH-5-a/V1 & $\mathrm{S}^{\mathrm{T}} \mathrm{R}^{\mathrm{V}}$ & 1998 & 0.2 & $>100$ \\
\hline HH-5-a/V2 & $\mathrm{S}^{\mathrm{T}} \mathrm{R}^{\mathrm{V}}$ & 1998 & 0.2 & $>100$ \\
\hline HH-5-a/V3 & $\mathrm{R}^{\mathrm{T}} \mathrm{R}^{\mathrm{V}}$ & 1998 & $>500$ & 1.3 \\
\hline HH-5-a/V4 & $\mathrm{S}^{\mathrm{T}} \mathrm{R}^{\mathrm{V}}$ & 1998 & 0.2 & $>100$ \\
\hline HL-7-1/Vc & $\mathrm{S}^{\mathrm{T}} \mathrm{R}^{\mathrm{V}}$ & 1998 & 0.1 & 57.4 \\
\hline HL-7-1/Vd & $\mathrm{S}^{\mathrm{T}} \mathrm{R}^{\mathrm{V}}$ & 1998 & 0.1 & 19.2 \\
\hline MD-6-a/Vb & $\mathrm{S}^{\mathrm{T}} \mathrm{R}^{\mathrm{V}}$ & 1998 & 0.4 & $>100$ \\
\hline MD-6-a/Vf & $\mathrm{S}^{\mathrm{T}} \mathrm{R}^{\mathrm{V}}$ & 1998 & 0.2 & $>100$ \\
\hline MD-6-a/Vh & $\mathrm{S}^{\mathrm{T}} \mathrm{R}^{\mathrm{V}}$ & 1998 & 0.3 & $>100$ \\
\hline MD-6-a/Vi & $\mathrm{S}^{\mathrm{T}} \mathrm{R}^{\mathrm{V}}$ & 1998 & 0.2 & $>100$ \\
\hline UG-2/V1 & $\mathrm{R}^{\mathrm{T}} \mathrm{R}^{\mathrm{V}}$ & 1997 & $>500$ & 1.4 \\
\hline
\end{tabular}

a Selected in 1997 or 1998 from fungicide-amended media. Conidium suspensions of isolates sensitive to both fungicides $\left(\mathrm{S}^{\mathrm{T}} \mathrm{S}^{\mathrm{V}}\right)$ were spread on minimal agar medium amended with a single fungicide (thiophanate-methyl, $10 \mu \mathrm{g} / \mathrm{ml}$, or vinclozolin, $5 \mu \mathrm{g} / \mathrm{ml}$ ) and placed at $20^{\circ} \mathrm{C}$ in the dark for 5 days. Colonies that appeared normal were subcultured on the same fungicide-amended medium from which they had been selected and then were transferred to unamended potato dextrose agar for continued growth and conidium production.

${ }^{\mathrm{b}} \mathrm{EC}_{50}$ values were calculated as the effective concentration of a fungicide that inhibited mycelium growth by $50 \%$ on fungicide-amended medium.

${ }^{c}$ Isolate numbers consisted of arbitrary uppercase letters to indicate the geographic site of collection (Table 1); a number corresponding to an individual piece of infected plant tissue; a lowercase letter, a or b, when two isolates were collected from the same piece of infected tissue; and a variant designation, based on whether variants were produced on thiophanate-methyl (T)- or vinclozolin (V)-amended medium and a selection number or letter.

${ }^{\mathrm{d}}$ Phenotypes were sensitive $(\mathrm{S})$ or resistant $(\mathrm{R})$ to thiophanate-methyl $\left(^{\mathrm{T}}\right.$ ) or vinclozolin $\left({ }^{\mathrm{V}}\right) ; \mathrm{EC}_{50}$ values $\geq 1 \mu \mathrm{g}$ of fungicide per $\mathrm{ml}$. indicated resistant isolates.

e The year variant isolates were selected. 

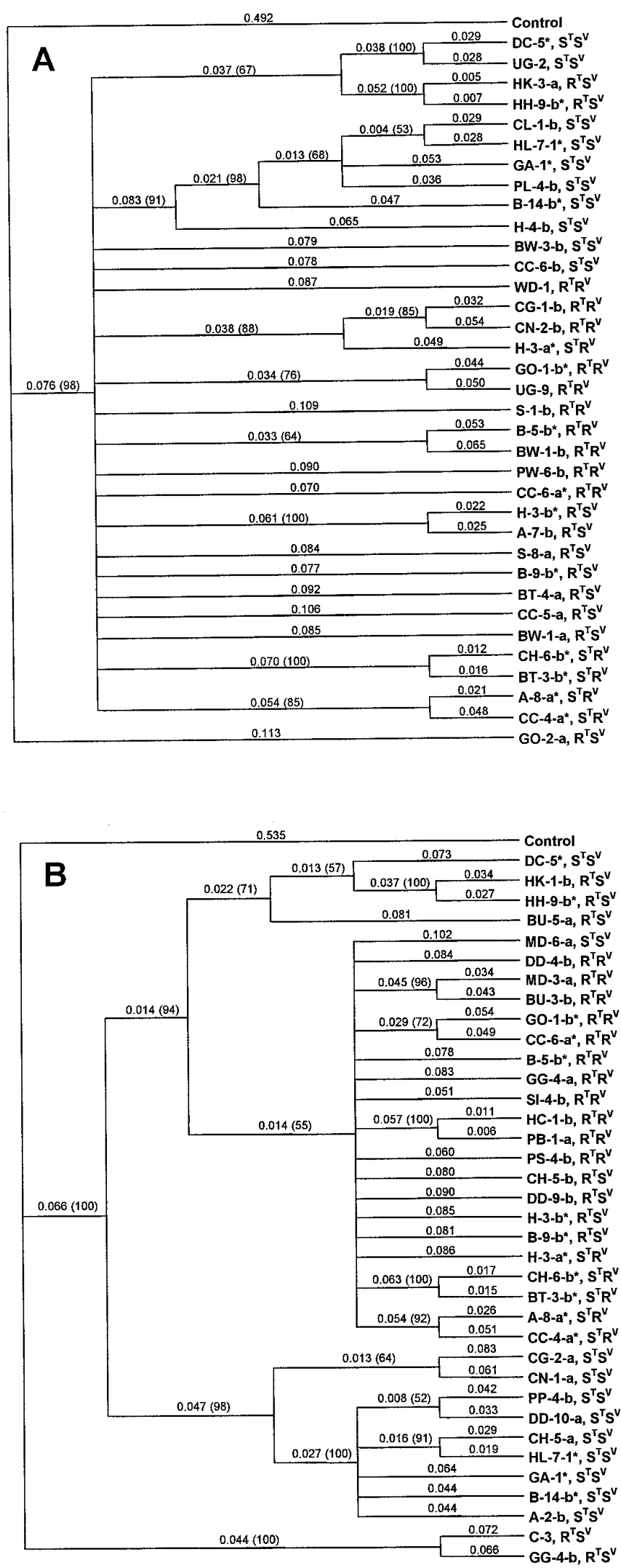

Fig. 1. Genetic relationships among 56 isolates of Botrytis cinerea resistant $(\mathrm{R})$ or sensitive $(\mathrm{S})$ to thiophanate-methyl ${ }^{\mathrm{T}}$ ) or vinclozolin $\left({ }^{\mathrm{V}}\right)$ collected from ornamental crops in commercial greenhouses in South Carolina. Isolates were divided into two sets for random amplified polymorphic DNA (RAPD) fingerprint analyses: A, Greenhouse set 1 had 35 isolates, and B, Greenhouse set 2 had 36 isolates; 15 isolates were common to both sets (*). Table 1 explains isolate numbers. Phenotype designations follow numbers. Mean character difference values and bootstrap confidence values [in ( )] are labeled above branches. The control was the RAPD profile of polymerase chain reactions without template DNA. Cladograms were constructed by PAUP software, version 4.0b2. ships among isolates resistant to thiophanate-methyl and included $6 \mathrm{~S}^{\mathrm{T}} \mathrm{S}^{\mathrm{V}}$ parent, 24 resistant variants (i.e., $19 \mathrm{R}^{\mathrm{T}} \mathrm{R}^{\mathrm{V}}$, and $5 \mathrm{R}^{\mathrm{T}} \mathrm{S}^{\mathrm{V}}$ ), and 6 greenhouse isolates resistant to thiophanate-methyl (i.e., 4 $\mathrm{R}^{\mathrm{T}} \mathrm{R}^{\mathrm{V}}$ and $2 \mathrm{R}^{\mathrm{T}} \mathrm{S}^{\mathrm{V}}$ ). A cladogram was constructed (Fig. 2B) from a data set with 184 informative characters. Isolates in this set that also were used in other fingerprint sets clustered similarly. For example, $\mathrm{S}^{\mathrm{T}} \mathrm{S}^{\mathrm{V}}$ isolates B-14-b, CH-5-a, and FL-4-b were common to Variant sets 1 and 2 and clustered together in both sets with a bootstrap value of $100 \%$. They were among the $12 \mathrm{~S}^{\mathrm{T}} \mathrm{S}^{\mathrm{V}}$ isolates that were clustered similarly in GH sets 1 and 2 (Fig. 1A and 1B, respectively). As in Variant set 1, fungicide-sensitive parent isolates clustered separately from thiophanate-methyl-resistant variants derived from them except for isolate CC-6-b, which clustered with one of its own $R^{T} R^{V}$ clonal derivatives and one $R^{T} R^{V}$ greenhouse isolate from the same location and away from other $S^{T} S^{V}$ parent isolates. Again, thiophanate-methyl-resistant variants with the same phenotype and same parent tended to cluster together, if at all, and clonal derivatives from the same parent with different phenotypes clustered independently. Three of the six resistant greenhouse isolates clustered with unrelated isolates with similar phenotypes, and the other three greenhouse isolates did not cluster.

Variant set 3. RAPD fingerprints of this set were examined to further investigate the relationships of fungicide-sensitive parent isolates $\left(\mathrm{S}^{\mathrm{T}} \mathrm{S}^{\mathrm{V}}\right)$ with variants that remained sensitive to thiophanate-methyl but were resistant to vinclozolin $\left(\mathrm{S}^{\mathrm{T}} \mathrm{R}^{\mathrm{V}}\right)$. This set included $8 \mathrm{~S}^{\mathrm{T}} \mathrm{S}^{\mathrm{V}}$ parent isolates, 23 variants (i.e., $20 \mathrm{~S}^{\mathrm{T}} \mathrm{R}^{\mathrm{V}}, 2 \mathrm{R}^{\mathrm{T}} \mathrm{R}^{\mathrm{V}}$, and $1 \mathrm{R}^{\mathrm{T}} \mathrm{S}^{\mathrm{V}}$ ), and $5 \mathrm{~S}^{\mathrm{T}} \mathrm{R}^{\mathrm{V}}$ greenhouse isolates, which also were included in $\mathrm{GH}$ sets 1 and 2 (Fig. $1 \mathrm{~A}$ and $1 \mathrm{~B}$, respectively). A cladogram for these isolates (Fig. 2C) was constructed from a data set with 196 informative characters. Variant set 3 corroborated the overall relationship between $S^{\mathrm{T}} \mathrm{S}^{\mathrm{V}}$ parents and $\mathrm{S}^{\mathrm{T}} \mathrm{R}^{\mathrm{V}}$ variants that was observed in Variant set 1 . In fact, the genetic relationship among $S^{\mathrm{T}} \mathrm{S}^{\mathrm{V}}$ parents and their $\mathrm{S}^{\mathrm{T}} \mathrm{R}^{\mathrm{V}}$ clonal derivatives was stronger than the relationship among unrelated $\mathrm{S}^{\mathrm{T}} \mathrm{S}^{\mathrm{V}}$ parents. All eight $\mathrm{S}^{\mathrm{T}} \mathrm{S}^{\mathrm{V}}$ parent isolates clustered with at least some of their $S^{T} R^{V}$ clonal derivatives. A cluster of 16 isolates that included 5 $\mathrm{S}^{\mathrm{T}} \mathrm{S}^{\mathrm{V}}$ parent isolates and their $11 \mathrm{~S}^{\mathrm{T}} \mathrm{R}^{\mathrm{V}}$ variants clustered with a bootstrap value of $98 \%$. Within this group were five clusters containing individual $S^{\mathrm{T}} \mathrm{S}^{\mathrm{V}}$ parent isolates and their $\mathrm{S}^{\mathrm{T}} \mathrm{R}^{\mathrm{V}}$ clonal derivatives with bootstrap values ranging from 87 to $99 \%$. For example, $\mathrm{S}^{\mathrm{T}} \mathrm{S}^{\mathrm{V}}$ parent isolate DD-10-a was clustered with its two $\mathrm{S}^{\mathrm{T}} \mathrm{R}^{\mathrm{V}}$ clonal derivatives with a bootstrap value of $96 \%$. The relationship of $\mathrm{S}^{\mathrm{T}} \mathrm{S}^{\mathrm{V}}$ parent $\mathrm{HH}-5-\mathrm{a}$ and its three $\mathrm{S}^{\mathrm{T}} \mathrm{R}^{\mathrm{V}}$ clonal derivatives corroborated results observed in Variant set 1 (Fig. 2A). $\mathrm{S}^{\mathrm{T}} \mathrm{R}^{\mathrm{V}}$ variants also were more similar to their $\mathrm{S}^{\mathrm{T}} \mathrm{S}^{\mathrm{V}}$ parents than to the five wild-type $S^{T} R^{V}$ isolates collected from greenhouses and included in this fingerprint set. Only one $\mathrm{S}^{\mathrm{T}} \mathrm{R}^{\mathrm{V}}$ greenhouse isolate, CC-4-a, clustered with a variant isolate of the same phenotype, BW-3-b/V1.

As in other fingerprint sets, variants with resistance to thiophanate-methyl were genetically very distant from their parents. Parent isolate GA-1 clustered with its three $\mathrm{S}^{\mathrm{T}} \mathrm{R}^{\mathrm{V}}$ clonal derivatives but not with its two thiophanate-methyl-resistant clonal derivatives, GA-1/T1 $\left(\mathrm{R}^{\mathrm{T}} \mathrm{S}^{\mathrm{V}}\right)$ and $\mathrm{GA}-1 / \mathrm{V} 2\left(\mathrm{R}^{\mathrm{T}} \mathrm{R}^{\mathrm{V}}\right)$. Similarly, parent isolate DC-5 clustered with its only $\mathrm{S}^{\mathrm{T}} \mathrm{R}^{\mathrm{V}}$ clonal derivative, DC-5/V2, but not with its $\mathrm{R}^{\mathrm{T}} \mathrm{R}^{\mathrm{V}}$ clonal derivative, DC-5/V1. Interestingly, the two $\mathrm{R}^{\mathrm{T}} \mathrm{R}^{\mathrm{V}}$ variant isolates $\mathrm{GA}-1 / \mathrm{V} 2$ and $\mathrm{DC}$ $5 / \mathrm{V} 1$ clustered together.

\section{DISCUSSION}

Genetic mechanisms for the development of resistance by many organisms to fungicides and other pesticides have been the subject of theoretical and experimental investigations for many years (26). Isolates of $B$. cinerea associated with ornamental crops that are resistant to the popular and commonly used fungicides thiophanate-methyl and vinclozolin occur widely on various crops around the world $(2,4,16)$; however, the genetic variation associated with this resistance has not been investigated fully. In this study, analyses 
of RAPD marker polymorphisms were used to study genetic variation and relatedness among isolates of $B$. cinerea sensitive and resistant to fungicides. Twelve primers provided a sufficient number of informative characters to construct cladograms and identify relationships among the isolates. RAPD profiles were consistent between trials with the same isolates, relationships among isolates common to different fingerprint sets were similar, and relationships identified with one set of isolates were confirmed and validated with other sets of independent isolates.

Cluster analyses of 56 greenhouse isolates of $B$. cinerea, from diverse geographic areas in South Carolina, were analyzed as 2 independent RAPD fingerprint sets and revealed a wide range of
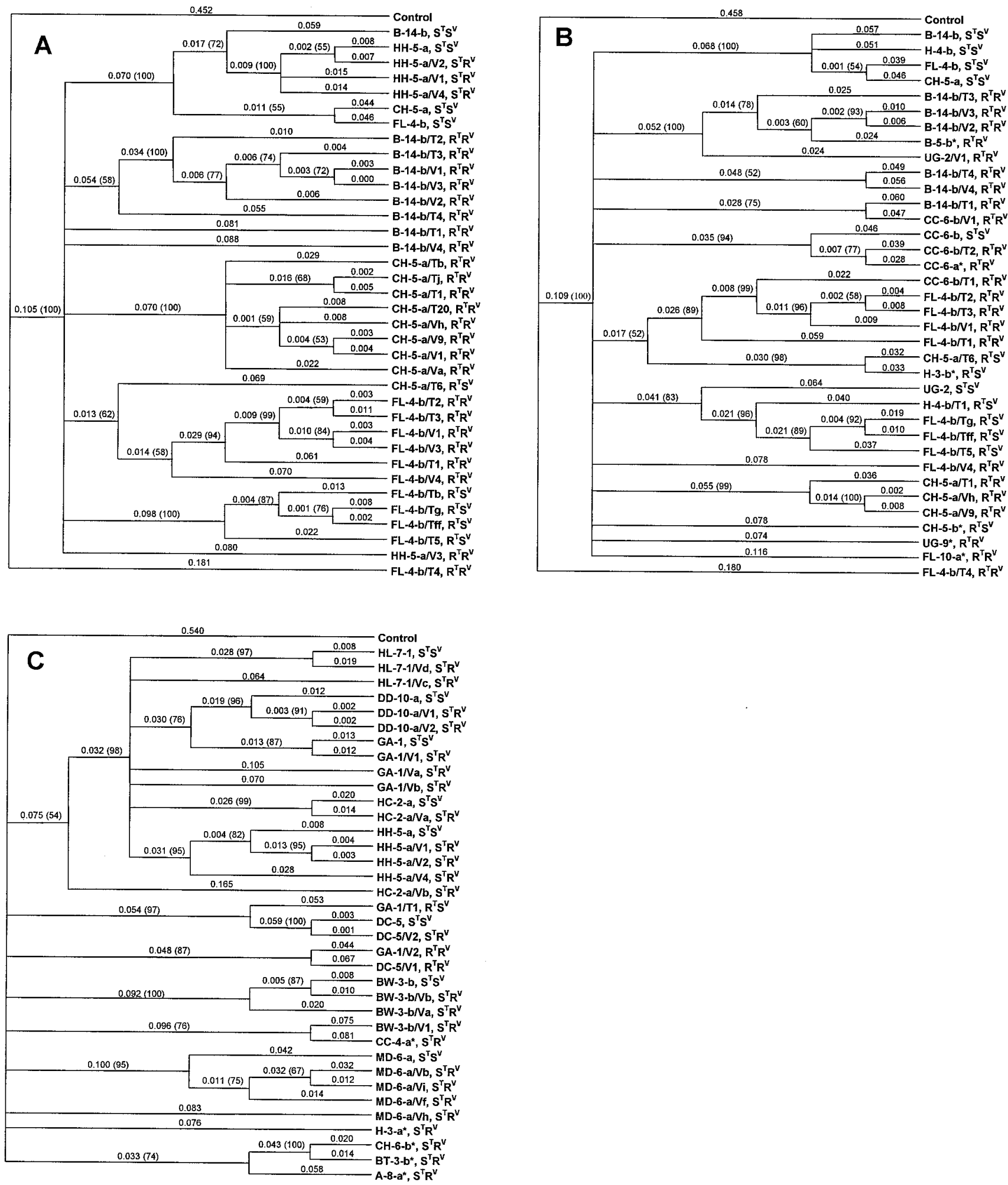

Fig. 2. Genetic relationships among 82 isolates, including 57 variant and 25 greenhouse isolates, of Botrytis cinerea that were resistant (R) or sensitive (S) to thiophanate-methyl $\left({ }^{\mathrm{T}}\right)$ or vinclozolin $\left({ }^{\mathrm{V}}\right)$. Isolates were separated into three sets of 36 isolates for random amplified polymorphic DNA (RAPD) fingerprint analyses: A, Variant set 1 had 32 variant isolates and 4 sensitive parent isolates $\left(S^{\mathrm{T}} S^{\mathrm{V}}\right)$; $\mathbf{B}$, Variant set 2 had 24 variant, $6 \mathrm{~S}^{\mathrm{T}} \mathrm{S}^{\mathrm{V}}$ parent, and 6 resistant greenhouse isolates $(*)$ $\left(4 \mathrm{R}^{\mathrm{T}} \mathrm{R}^{\mathrm{V}}, 2 \mathrm{R}^{\mathrm{T}} \mathrm{S}^{\mathrm{V}}\right)$; and $\mathrm{C}$, Variant set 3 had 23 variant, $8 \mathrm{~S}^{\mathrm{T}} \mathrm{S}^{\mathrm{V}}$ parent, and $5 \mathrm{~S}^{\mathrm{T}} \mathrm{R}^{\mathrm{V}}$ greenhouse isolates $(*)$. All variant isolates were produced in the laboratory from $\mathrm{S}^{\mathrm{T}} \mathrm{S}^{\mathrm{V}}$ greenhouse isolates (Table 2). Phenotype designations follow isolate numbers. Mean character difference values and bootstrap confidence values (in parentheses) are labeled above branches. The control was the RAPD profile of polymerase chain reactions without templateDNA. Cladograms were constructed by PAUP software, version 4.0b2. 
genetic differences. RAPD profiles were very similar among isolates sensitive to both thiophanate-methyl and vinclozolin $\left(\mathrm{S}^{\mathrm{T}} \mathrm{S}^{\mathrm{V}}\right)$, usually with high bootstrap confidence values assigned to the nodes. Greenhouse isolates resistant to one or both fungicides were more diverse genetically and frequently were not clustered with other isolates, suggesting greater diversity among genotypes of fungicide-resistant isolates. However, when these isolates were clustered together, isolates within a cluster had the same phenotype.

To further investigate and elucidate genetic relationships observed among greenhouse isolates, fungicide-resistant variant isolates derived from fungicide-sensitive greenhouse isolates $\left(\mathrm{S}^{\mathrm{T}} \mathrm{S}^{\mathrm{V}}\right)$ were selected, and RAPD fingerprints for three sets of variant isolates were generated and subjected to cluster analyses. Clonal derivatives sensitive to thiophanate-methyl but resistant to vinclozolin $\left(\mathrm{S}^{\mathrm{T}} \mathrm{R}^{\mathrm{V}}\right)$ were very similar genetically to their $\mathrm{S}^{\mathrm{T}} \mathrm{S}^{\mathrm{V}}$ parents. This suggests that only minor genetic changes were involved in conferring vinclozolin resistance. Resistance to dicarboximides, such as vinclozolin, is believed to be encoded by Dafl (5), and it is possible that the similarity among genotypes of $\mathrm{S}^{\mathrm{T}} \mathrm{S}^{\mathrm{V}}$ parents and $S^{T} R^{V}$ clonal derivatives is the result of a single copy of a resistant allele.

In a previous study (5), wild-type isolates resistant to dicarboximides nearly always exhibited a low level of resistance (i.e., $\mathrm{EC}_{50}$ for mycelium growth from 1 to $3 \mu \mathrm{g} / \mathrm{ml}$ ) while variants selected in the laboratory commonly had high levels of resistance (i.e., $\mathrm{EC}_{50}$ for mycelium growth $>100 \mu \mathrm{g} / \mathrm{ml}$ ). Of the variant isolates produced in this study, many of those resistant only to vinclozolin $\left(\mathrm{S}^{\mathrm{T}} \mathrm{R}^{\mathrm{V}}\right)$ exhibited high levels of resistance to this fungicide, but none of the isolates resistant to both fungicides $\left(R^{T} R^{V}\right)$ were highly resistant to vinclozolin. In addition, few of the greenhouse isolates studied previously (42) had high levels of resistance to vinclozolin. In cladograms produced in this study, the close relationship of $\mathrm{S}^{\mathrm{T}} \mathrm{S}^{\mathrm{V}}$ isolates and their $\mathrm{S}^{\mathrm{T}} \mathrm{R}^{\mathrm{V}}$ clonal derivatives occurred regardless of the level of vinclozolin resistance among the $S^{T} R^{V}$ variants. Consequently, there appears to be little genetic difference between isolates with low or high levels of resistance to vinclozolin.

In all three sets of variant isolates studied here, thiophanatemethyl-resistant isolates clustered independently from their fungicide-sensitive parents, except for one instance in Variant set 2. For thiophanate-methyl-resistant variants from the same parents, isolates with the same phenotypes $\left(\mathrm{R}^{\mathrm{T}} \mathrm{R}^{\mathrm{V}}\right.$ or $\left.\mathrm{R}^{\mathrm{T}} \mathrm{S}^{\mathrm{V}}\right)$ were genetically similar whereas isolates with different phenotypes $\left(\mathrm{R}^{\mathrm{T}} \mathrm{R}^{\mathrm{V}}\right.$ and $\left.\mathrm{R}^{\mathrm{T}} \mathrm{S}^{\mathrm{V}}\right)$ were genetically different. Consequently, genetic changes associated with resistance were more important than clonal ties in determining genetic relationships among these isolates. Thiophanate-methyl-resistant variants, either $\mathrm{R}^{\mathrm{T}} \mathrm{R}^{\mathrm{V}}$ or $\mathrm{R}^{\mathrm{T}} \mathrm{S}^{\mathrm{V}}$, from different parents also were genetically distinct. Therefore, among the thiophanate-methyl-resistant isolates examined in this study, both the inherent variability among isolates from different thalli and genetic changes associated with thiophanate-methyl resistance were important determinants of genetic relationships.

The genetic changes associated with thiophanate-methyl resistance appeared to be major, based on the lack of relatedness among resistant variants and sensitive parents. This might indicate the involvement of multiple copies of alleles of $M b c 1$. Source and magnitude of genetic variability within $B$. cinerea have been attributed to the multinucleate character of this fungus, parasexual exchange of nuclei between hyphae, or possible differences in ploidy level among isolates $(3,11,25,35,36)$. Other explanations for the large genetic changes associated with fungicide resistance that we observed may be selection for modifier genes (22) such as in dicarboximide-resistant isolates of Neurospora crassa (10) and benzimidazole-resistant isolates of Fusarium oxysporum (28) or extragenic suppressor mutations of $\beta$-tubulin mutants (41) that caused reversion to benomyl sensitivity in Coprinus cinereus $(17,18)$.
To produce fungicide-resistant variants for this study, fungicidesensitive greenhouse isolates $\left(\mathrm{S}^{\mathrm{T}} \mathrm{S}^{\mathrm{V}}\right)$ were placed on agar medium amended with only one fungicide - either thiophanate-methyl or vinclozolin. Unexpectedly, when variants were selected from a fungicide-amended medium, instead of finding variants resistant to only the fungicide used in the medium $\left(R^{\mathrm{T}} \mathrm{S}^{\mathrm{V}}\right.$ or $\left.\mathrm{S}^{\mathrm{T}} \mathrm{R}^{\mathrm{V}}\right)$, some variants were resistant to both fungicides $\left(\mathrm{R}^{\mathrm{T}} \mathrm{R}^{\mathrm{V}}\right)$. Ordered tetrad analysis of ascospores from Botryotinia fuckeliana, the teleomorph of $B$. cinerea, indicated that the two genes involved in resistance to benzimidazole and dicarboximide fungicides, $\mathrm{Mbcl}$ and Dafl, respectively, probably were linked; the calculated map distance between them was approximately 47 map units (6). A loose linkage also was observed by Weeds et al. (40). This linkage may explain why some parent isolates sensitive to both fungicides $\left(\mathrm{S}^{\mathrm{T}} \mathrm{S}^{\mathrm{V}}\right)$ generated doubly resistant clonal derivatives $\left(\mathrm{R}^{\mathrm{T}} \mathrm{R}^{\mathrm{V}}\right)$ when exposed to a medium amended with only one fungicide. Cluster analysis of $\mathrm{R}^{\mathrm{T}} \mathrm{R}^{\mathrm{V}}$ clonal derivatives from the same fungicidesensitive parent isolates did not appear to differentiate isolates on the basis of exposure to thiophanate-methyl or vinclozolin or the year in which resistant variants were selected (i.e., 1997 or 1998).

The high incidence of resistance to either benzimidazole or dicarboximide fungicides that occurs in populations of $B$. cinerea worldwide has been explained by the constant selection pressure created by the continued use of these fungicides over many years. However, some researchers studying $B$. cinerea have speculated that benzimidazole resistance might somehow promote the acquisition of resistance to dicarboximide fungicides $(13,31)$ and, therefore, the occurrence of isolates resistant to both fungicides $\left(R^{T} R^{V}\right)$. Based on our research, it is possible that $R^{T} R^{V}$ variants can develop after sensitive wild-type isolates of $B$. cinerea are exposed to either thiophanate-methyl or vinclozolin-which may provide another explanation for the high incidence of $\mathrm{R}^{\mathrm{T}} \mathrm{R}^{\mathrm{V}}$ isolates found in agricultural fields and greenhouses around the world.

\section{ACKNOWLEDGMENTS}

Technical Contribution No. 4516 of the South Carolina Agriculture and Forestry Research System, Clemson University, Clemson, SC. This research was supported in part by a grant (SC01646) from the Clemson University Program for Enhancement in Research and Extension in Ornamental Horticulture. We thank H. Leung for excellent editorial advice; W. V. Baird and E. I. Zehr for reviewing the manuscript; S. S. Kay for technical support; and W. A. Cleary Chemical Corporation and BASF Corporation for providing fungicides.

\section{LITERATURE CITED}

1. Bentley, S., Pegg, K. G., and Dale, J. L. 1995. Genetic variation among a world-wide collection of isolates of Fusarium oxysporum f. sp. cubense analysed by RAPD-PCR fingerprinting. Mycol. Res. 99:1378-1384.

2. Brent, K. J. 1995. Fungicide resistance in crop pathogens: How can it be managed? International Group of National Associations of Manufacturers of Agrochemical Products (GIFAP), Brussels.

3. Büttner, P., Koch, F., Voigt, K., Quidde, T., Risch, S., Blaich, R., Bruckner, B., and Tudzynski, P. 1994. Variations in ploidy among isolates of Botrytis cinerea: Implications for genetic and molecular analyses. Curr. Genet. 25:445-450.

4. Daughtrey, M. L., Wick, R. L., and Peterson, J. L. 1995. Compendium of Flowering Potted Plant Diseases. The American Phytopathological Society, St. Paul, MN.

5. Faretra, F., and Pollastro, S. 1991. Genetic basis of resistance to benzimidazole and dicarboximide fungicides in Botryotinia fuckeliana (Botrytis cinerea). Mycol. Res. 95:943-951.

6. Faretra, F., and Pollastro, S. 1996. Genetic studies of the phytopathogenic fungus Botryotinia fuckeliana (Botrytis cinerea) by analysis of ordered tetrads. Mycol. Res. 100:620-624.

7. Forey, P. L., Humphries, C. J., Kitching, I. J., Scotland, R. W., Siebert, D. J., and Williams, D. M. 1992. Cladistics: A Practical Course in Systematics. Oxford University Press, Oxford.

8. Garber, M. P., Hudson, W. G., Norcini, J. G., Thomas, W. A., Jones, R. K., and Bondari, K. 1997. Biologic and Economic Assessment of Pest 
Management in the United States Greenhouse and Nursery Industry. Cooperative Extension Service, University of Georgia, Athens.

9. Georgopoulos, S. G., and Skylakakis, G. 1986. Genetic variability in the fungi and the problem of fungicide resistance. Crop Prot. 5:299-305.

10. Grindle, M., and, Dolderson, G. H. 1986. Effects of a modifier gene on the phenotype of a dicarboximide-resistant mutant of Neurospora crassa. Trans. Br. Mycol. Soc. 87:457-460.

11. Hansen, H. N., and Smith, R. E. 1932. The mechanism of variation in imperfect fungi: Botrytis cinerea. Phytopathology 22:953-964.

12. Hillis, D. M., Mable, B. K., and Moritz, C. 1996. Applications of molecular systematics: The state of the field and a look to the future. Pages 515-543 in: Molecular Systematics. D. M. Hillis, C. Moritz, and B. K. Mable, eds. Sinauer Associates, Sunderland, MA.

13. Hisada, Y., Kato, T., and Noda, C. 1984. Biological properties of procymidone-resistant field isolates of Botrytis cinerea. Ann. Phytopathol. Soc. Jpn. 50:590-599.

14. Huff, D. R., Bunting, T. E., and Plumley, K. A. 1994. Use of random amplified polymorphic DNA markers for the detection of genetic variation in Magnaporthe poae. Phytopathology 84:1312-1316.

15. Hunter, T., Brent, K. J., Carter, G. A., and Hutcheon, J. A. 1987. Effects of fungicide spray regimes on incidence of dicarboximide resistance in grey mould (Botrytis cinerea) on strawberry plants. Ann. Appl. Biol. 110:515-525.

16. Jarvis, W. R. 1992. Managing Diseases in Greenhouse Crops. The American Phytopathological Society, St. Paul, MN.

17. Kamada, T., Hirami, H., Sumiyoshi, T., Tanabe, S., and Takemaru, T. 1990. Extragenic suppressor mutations of a $\beta$-tubulin mutation in the basidiomycete Coprinus cinereus: Isolation and genetic and biochemical analyses. Curr. Microbiol. 20:223-228.

18. Kamada, T., Sumiyoshi, T., and Takemaru, T. 1989. Mutations in $\beta$ tubulin block transhyphal migration of nuclei in dikaryosis in the homobasidiomycete Coprinus cinereus. Plant Cell Physiol. 30:1073-1080.

19. Katan, T. 1982. Resistance to 3,5-dichlorophenyl- $N$-cyclic imide ('dicarboximide') fungicides in the grey mould pathogen Botrytis cinerea on protected crops. Plant Pathol. 31:133-141.

20. Kerssies, A., Bosker-van Zessen, A. I., Wagemakers, C. A. M., and van Kan, J. A. L. 1997. Variation in pathogenicity and DNA polymorphism among Botrytis cinerea isolates sampled inside and outside a glasshouse. Plant Dis. 81:781-786.

21. Leroux, P., and Clerjeau, M. 1985. Resistance of Botrytis cinerea Pers. and Plasmopara viticola (Berk. \& Curt.) Berl. and de Toni to fungicides in French vineyards. Crop Prot. 4:137-160.

22. Levin, B. R. 1986. Population biology of pesticide resistance: Bridging the gap between theory and practical applications. Pages 143-156 in: Pesticide Resistance: Strategies and Tactics for Management. National Academy Press, Washington, DC.

23. Locher, F. J., Lorenz, G., and Beetz, K.-J. 1987. Resistance management strategies for dicarboximide fungicides in grapes: Results of six years' trial work. Crop Prot. 6:139-147.

24. Locke, T., and Fletcher, J. T. 1988. Incidence of benomyl and iprodione resistance in isolates of Botrytis cinerea in tomato crops in England and Wales in 1986. Plant Pathol. 37:381-384.

25. Lorbeer, J. W. 1980. Variation in Botrytis and Botryotinia. Pages 19-39 in: The Biology of Botrytis. J. R. Coley-Smith, K. Verhoeff, and W. R. Jarvis, eds. Academic Press, New York.

26. May, R. M. 1985. Evolution of pesticide resistance. Nature 315:12-13.
27. Möller, E. M., Bahnweg, G., Sandermann, H., and Geiger, H. H. 1992. A simple and efficient protocol for isolation of high molecular weight DNA from filamentous fungi, fruit bodies, and infected plant tissues. Nucleic Acids Res. 20:6115-6116.

28. Molnar, A., Hornok, L., and Pesti, M. 1985. The high level of benomyl tolerance in Fusarium oxysporum is determined by the synergistic interaction of two genes. Exp. Mycol. 9:326-333.

29. Moorman, G. W., and Lease, R. J. 1992. Benzimidazole- and dicarboximide-resistant Botrytis cinerea from Pennsylvania greenhouses. Plant Dis. 76:477-480.

30. Pak, H. A., Beever, R. E., and Laracy, E. P. 1990. Population dynamics of dicarboximide-resistant strains of Botrytis cinerea on grapevine in New Zealand. Plant Pathol. 39:501-509.

31. Panayotakou, M., and Malathrakis, N. E. 1983. Resistance of Botrytis cinerea to dicarboximide fungicides in protected crops. Ann. Appl. Biol. 102:293-299.

32. Pipe, N. D., Buck, K. W., and Brasier, C. M. 1995. Genomic fingerprinting supports the separation of Ophiostoma piceae into two species. Mycol. Res. 99:1182-1186.

33. Sambrook, J., Fritsch, E. F., and Maniatis, T. 1989. Molecular Cloning: A Laboratory Manual. 2nd ed. Cold Spring Harbor Laboratory Press, Cold Spring Harbor, NY.

34. Sharma, T. R., and Tewari, J. P. 1998. RAPD analysis of three Alternaria species pathogenic to crucifers. Mycol. Res. 102:807-814.

35. Shirane, N., Masuko, M., and Hayashi, Y. 1988. Nuclear behavior and division in germinating conidia of Botrytis cinerea. Phytopathology 78:1627-1630.

36. Shirane, N., Masuko, M., and Hayashi, Y. 1989. Light microscopic observation of nuclei and mitotic chromosomes of Botrytis species. Phytopathology 79:728-730.

37. Stehmann, C., and De Waard, M. A. 1996. Sensitivity of populations of Botrytis cinerea to triazoles, benomyl, and vinclozolin. Eur. J. Plant Pathol. 102:171-180.

38. Swofford, D. L., Olsen, G. J., Waddell, P. J., and Hillis, D. M. 1996. Phylogenetic inference. Pages 407-514 in: Molecular Systematics. D. M. Hillis, C. Moritz, and B. K. Mable, eds. Sinauer Associates, Sunderland, MA.

39. van der Vlugt-Bergmans, C. J. B., Brandwagt, B. F., van't Klooster, J. W., Wagemakers, C. A. M., and van Kan, J. A. L. 1993. Genetic variation and segregation of DNA polymorphisms in Botrytis cinerea. Mycol. Res. 97:1193-1200.

40. Weeds, P. L., Beever, R. E., and Long, P. G. 1998. New genetic markers for Botrytis cinerea (Botryotinia fuckeliana). Mycol. Res. 102:791-800.

41. Yarden, O., and Katan, T. 1993. Mutations leading to substitutions at amino acids 198 and 200 of beta-tubulin that correlate with benomylresistance phenotypes of field strains of Botrytis cinerea. Phytopathology 83:1478-1483.

42. Yourman, L. F., and Jeffers, S. N. 1999. Resistance to benzimidazole and dicarboximide fungicides in greenhouse isolates of Botrytis cinerea. Plant Dis. 83:569-575.

43. Yourman, L. F., Jeffers, S. N., and Dean, R. A. 1999. RAPD analysis of isolates of Botrytis cinerea sensitive and resistant to benzimidazole and dicarboximide fungicides. (Abstr.) Phytopathology 89 (suppl.):S88.

44. Yunis, H., and Elad, Y. 1989. Survival of dicarboximide-resistant strains of Botrytis cinerea in plant debris during summer in Israel. Phytoparasitica 17:13-21. 